\title{
THE IMPACT OF PERCEIVED VALUE, DESTINATION SERVICE QUALITY AND TOURIST SATISFACTION ON DESTINATION LOYALTY AMONG INTERNATIONAL TOURISTS VISITING MALAYSIA
}

\author{
Mahadzirah Mohamad ${ }^{1}$ \\ Faculty of Management and Business, \\ Universiti Sultan Zainal Abidin, Kuala Terengganu, 21300 Terengganu, Malaysia. \\ (Email: mahadzirahmd@unisza.edu.my) \\ Nur Izzati Ab Ghani \\ Centre for Fundamental Studies, \\ Universiti Sultan Zainal Abidin, Kuala Terengganu, 21300 Terengganu, Malaysia. \\ (Email: izzatighani@unisza.edu.my) (Corresponding Author) \\ Muhamad Nasyat Muhamad Nasir ${ }^{3}$ \\ Faculty of Management and Business, \\ Universiti Sultan Zainal Abidin, Kuala Terengganu, 21300 Terengganu, Malaysia. \\ (Email: nasyatnasir91@gmail.com)
}

Received date: $30-05-2019$

Revised date: 07-07-2019

Accepted date: 18-07-2019

Published date: 11-09-2019

To cite this document: Mohamad, M., Ab Ghani, N. I., \& Nasir, M. N. M. (2019). The Impact of Perceived Value, Destination Service Quality and Tourist Satisfaction on Destination Loyalty among International Tourists Visiting Malaysia. Journal of Tourism, Hospitality and Environment Management, 4(16), 10-26.

DOI: $10.35631 /$ JTHEM.416002

\begin{abstract}
The competitive situation and challenges within the tourism industry worldwide entailed a better understanding of destination loyalty's determinants in achieving Malaysia's aspiration to retain its international reputation as one of the most desirable tourist destinations in Asia. Literature proved that factors such as perceived value, service quality and tourist satisfaction could influence in improving destination loyalty. In view of this, there is a need to examine the influence of several constructs namely perceived value, service quality and tourist satisfaction that can contribute to the loyalty of international tourists towards Malaysia as it was suggested in the literature review. Therefore, the main objectives of this study were to examine the influence of perceived value and service quality on tourist satisfaction, which in turn would influence destination loyalty. In this study, tourist satisfaction was treated as the mediating variable. The proposed model was tested using structural equation modeling on a sample of 337 foreign tourists selected using random sampling method. The study was conducted from August 2014 to October 2014. The proposed model achieved acceptable goodness-of-fit. The requirements for reliability and validity were also met. The results of the empirical study indicated that perceived value influenced tourist satisfaction and destination loyalty. In addition, the findings revealed that service quality had a significant effect on satisfaction. However, service quality had no significant effect on
\end{abstract}


destination loyalty. Moreover, the findings indicated that tourist satisfaction had a full mediating effect on the relationship between service quality and destination loyalty. The study contributed to a better understanding of behavioral factors that would represent a sustainable source for increasing customer retention at the level of individual providers as well as a destination as a whole. Individual providers should focus on delivering quality services related to accommodation, information and facilities, health and hygiene, and shopping that were associated with the visitor's travel experience. Aspects of perceived value identified in the study could be used as a strategic tool in managing tourism offerings which could enhance the destination's competitive edge.

Keywords: Perceived Value, Destination Service Quality, Tourist Satisfaction, Destination Loyalty, Malaysia

\section{Introduction}

Tourism was declared as one of the most important economic activities in the world (Hallem and Barth, 2011) as it can generate destination's tourist receipts, income, provide employment opportunity, government revenue and foreign exchange earnings (Bhuiyan, Siwar and Ismail, 2013; Chen and Tsai, 2007). World Tourism Organization (2016a) reported that tourism has contributed 10 percent of global gross domestic product (GDP) and 6 percent of the world's total exports as more than one billion tourists travelling to international destinations every year. As a result, most of the countries have been affected positively from tourism industry through increasing the living standards of citizens, contributing to the balance payments, accumulating foreign exchange reserves, enhancing production of goods and services and generate government returns in terms of taxes and profits (Paramati, Alam, \& Chen, 2017). Due to the positive contribution in this sector, most of the countries in the world have taken initiatives to enhance and stimulate the development of their tourism industry further (Othman, Salleh and Sarmidi, 2012). In Malaysia, tourism is chosen as the second engine for the growth of nation to develop the global competitiveness (Bhuiyan et al., 2013) as Malaysia has become one of the most important tourist destinations in the world (Mosbah and Abd $\mathrm{Al}$ Khuja, 2014). Evidently, in Southeast Asia region, Malaysia has been recognized as the second most tourist friendly tourism destination for the year 2017 (Travel and Tourism Competitiveness Report, 2017). Tourism sector in Malaysia also contributed to the employment opportunity. According to World Travel and Tourism Council (2012 and 2013), this sector has generated 1,599,000 jobs in 2011 and it increased to 1,708,500 jobs in 2012 . During 2013, the sector has supported $1,857,500$ jobs and it had slightly decreased into $1,770,000$ jobs in 2014. The number continued to decrease to $1,576,000$ in 2015. Despite the total employment in 2015 has decreased, it has increase to 1,700,500 in 2016 to 1,704,500 in 2017. World Travel and Tourism Council (2018) forecasted total employment will increase by $2,356,000$ jobs by 2028. Acknowledging the great potentials in the tourism industry, the Malaysia Tourism Transformation Programme (MTTP) aimed to achieve the targets of attracting 36 million foreign tourists generating the sum of RM168 billion in tourist receipts in the year 2020 (Menteri, Jabatan Perdana, 2010).

Despite the tourism industry in Malaysia being identified as one of the National Key Economic Areas (NKEA) in the Government Transformation Programme, it could not avoid from being facing with serious challenge. Recently, the sector experienced a fluctuating declining trend of growth rate in the international tourists' arrivals between 2001 and 2017 (http://mytourismdata.tourism.gov.my). Hence, one of the challenges was to maintain a stable 
arrivals growth rate among international tourist. The unstable and declining rate of tourists' arrivals indicated that the tourism industry was very competitive. In a competitive market it is very important to focus on examining tourist destination loyalty exhibited through their intention to return and recommend through word-of-mouth (Mohamad et al., 2012). This information further illustrates the importance of studying destination loyalty and also its antecedents.

A review of the literature reveals that loyalty is important to the destination providers as loyal tourists who are faced with increasingly attractive destination competitive offers or by their own shortcoming will fix firmly their relationship with the destination that they used to visit before this (Mazlina et al., 2012). The concept of destination loyalty has been used by academics and practitioners for a long time as a significant benchmark for developing valuable business strategies (Oppermann, 2000). This is due to the fact that, a better understanding on the destination loyalty among tourists is crucial for destination marketing managers to forecast the success of destination management in managing the tourism destination ( $\mathrm{Wu}, 2016)$. Individuals may consider the need to revisit the familiar destination (Campón et al., 2013). Deng and Pierskalla (2011) suggested destination loyalty may be directly affected by past experience, for example repeat visit, or indirectly affected through the effect of past experience on other factors namely perceived value or satisfaction.

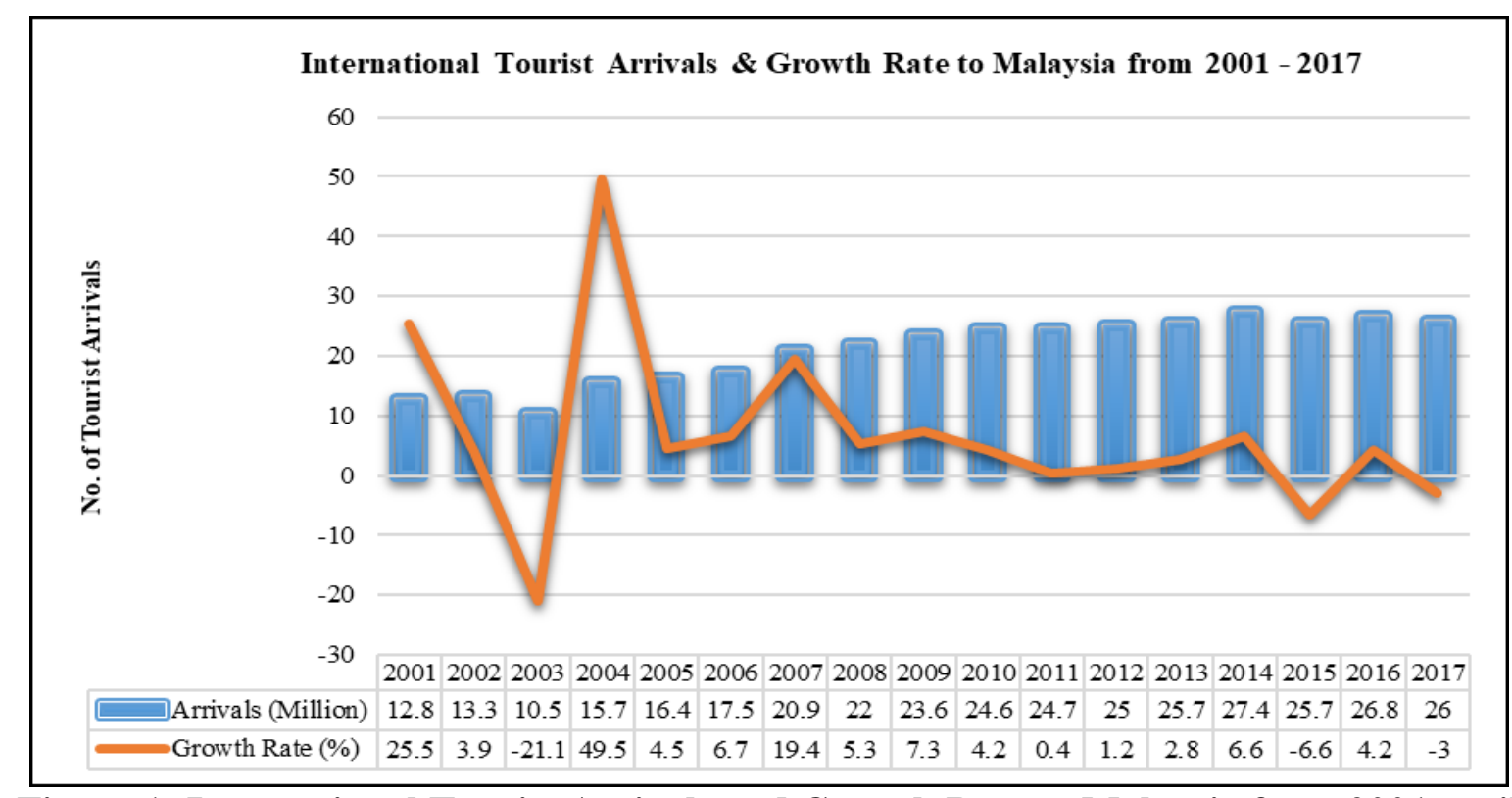

Figure 1: International Tourist Arrivals and Growth Rate to Malaysia from 2001 until 2017

Source: http://mytourismdata.tourism.gov.my/

A great deal of research has been allocated to investigate the determinants of destination loyalty, namely perceived value, service quality and tourist satisfaction, as they are considered important phenomenon at the management level (Kim et al., 2013; Sun et al., 2013; Yoon and Uysal, 2005). In addition, Žabkar et al. (2010) believed that in tourism, high service quality and resulting satisfaction lead to positive word-of-mouth endorsements, referrals, and repeat visits, which ultimately affect the financial performance of suppliers associated with the tourism industry. Therefore, the aims of this study were as follows:

1. To examine the effect of perceived value on tourist satisfaction. 
2. To examine the effect of perceived value on destination loyalty.

3. To examine the effect of service quality on tourist satisfaction.

4. To examine the effect of service quality on destination loyalty.

5. To examine the effect of tourist satisfaction on destination loyalty.

6. To identify the mediating role of tourist satisfaction in the relationship between perceived value and destination loyalty.

7. To identify the mediating role of tourist satisfaction in the relationship between service quality and destination loyalty.

\section{Literature Review}

\section{Destination Loyalty}

Competitions among destination marketing will become greater in the year to come (Wu, 2015). Thus, increasing a better understanding of why tourists are loyal to a destination and what drives loyalty is crucial $(\mathrm{Wu}, 2015)$ as a study on loyalty is broadly accepted as a major driving force for the success of businesses (Alizadeh and Saghafi, 2014). Destination loyalty can be defined as recommending the destination to others by a satisfied tourist (Wang et al., 2009). According to Kaur and Soch (2012), in the marketing literature, loyalty can bring practical benefits through increasing repeat patronage and saving marketing costs by spreading by word-of-mouth (Mao and Zhang, 2012). It is important to retain loyal tourists rather than winning new ones (Tiru et al., 2010). This is because Schiffman and Kanuk (2007) claimed that to win new customers is more expensive compared to keeping existing customers. Studies have shown that small reductions in customer defection can generate significant increase in profits as (1) loyal tourists pay less attention to competitors' destination and are less price sensitive; (2) loyal tourists repeat visit; (3) servicing existing tourists who are familiar with the destination is cheaper; (4) loyal tourists recommend to others (Schiffman and Kanuk, 2007); and (5) loyal tourists willing to give more positive word-of-mouth (Phillips et al., 2011).

\section{Perceived Value}

Lately, a study on customer value has become an area of interest to the marketers as it appears as a key determined of consumer decision-making (Eid and El-Gohary, 2014). However, as claimed by Bajs (2015), a study on perceived value in the context of tourist destination is underexplored. According to Wen (2011, p.80), "perceived value is defined as the sacrifice paid by the consumer to obtain a product or service, such sacrifice including monetary and non-monetary".

Prior studies in the tourism literature have studies the relationship between perceived value and tourist satisfaction. For example, a study conducted by Moutinho et al. (2012), Sun et al. (2013) and Rajaratnam et al. (2014) showed that customers who have positive perception of value for money can cause customer satisfaction. Furthermore, several recent studies (Hallak, Assaker \& El- Haddad, 2018; Sato, Gipson, Todd, \& Harada, 2018; Matsuoka, Hallak, Murayama, \& Akiike, 2017) found that perceived value has a significant impact on tourist satisfaction. In addition, empirical research disclosed that perceived value has positive impact on both future behavioural intentions and behaviours (Chen and Tsai, 2007). For example, Mechinda et al. (2010); Wang et al. (2016) found that perceived value has influence on destination loyalty. Thus, the following hypotheses were developed:

H1: Perceived value has a direct effect on tourist satisfaction. 
H2: Perceived value has a direct effect on destination loyalty.

\section{Destination Service Quality}

Destination service quality is referred as a service performance at the attribute level in the context of tourism study (Chen and Chen, 2010). Service quality has become very imperative in this age of increasing competition in destination management. By providing high-quality services, tourist destinations are more likely to entice both first-time and repeat visitors. Tourists who have a quality experience are likely to communicate favourable reports to friends and relatives. This creates both repeat business and potential for new business (Vassiliadis et al., 2008). According to Tosun et al. (2015, p. 223), "service quality is defined as tourists' valuation of the performance of services consumed in a given tourist destination". Destination loyalty is the major outcome of a successful delivery of tourism service quality and experience in a tourism destination (Akroush et al., 2016). According to Leong et al. (2015), the relationship between service quality and customer satisfaction has been broadly debated where some researchers state that service quality can produce customer satisfaction while others do not agree or argue that there is no relationship between these two constructs. Khan et al. (2013) claimed that, destinations that provide better service quality can attract tourists and cause tourist satisfaction. In addition, several literatures found that service quality is the antecedent of tourist satisfaction (Silvestri, Aquilani, \& Ruggieri, 2017; Hallak, Assaker \& El-Haddad, 2018) and destination loyalty (Priporas, Stylos, Vedanthachari, \& Santiwatana, 2017; Hallak, Assaker \& El-Haddad, 2018). Thus, the following hypotheses are provided:

H3: Service quality has a direct effect on tourist satisfaction.

H4: Service quality has a direct effect on destination loyalty.

\section{Tourist Satisfaction}

Customer satisfaction has become the key challenge for destination managers, since the marketing strategy is focussed on attracting more tourists to the destination (Meleddu et al., 2015). According to Phillips et al. (2011, p. 95) tourist satisfaction is defined as "the overall contented feeling that a tourist felt from visiting a destination, which fulfilled his travel expectations and needs". A study on satisfaction would help to provide information about how well a destination can meet tourist needs (Mao and Zhang, 2014).

Despite tourist satisfaction being vital in tourism management, Shiang et al. (2011) claimed that tourist satisfaction is identified as a function of perceived performance and expectations and studies in customer behaviour found that customers who are only just satisfied will easily switch over when a better offer comes along (Shiang et al., 2011). Enhancing tourists' satisfaction levels and destination loyalty are extremely crucial and necessary in tourism destination management (Khuong and Ha, 2014). Alegra and Garau (2010) believed that in a person's assessment of the destination, different attributes are important to determine the overall satisfaction and tourist's intention to return. Thus, this study proposed the following hypotheses:

H5: Tourist satisfaction has a direct effect on destination loyalty.

H6: Tourist satisfaction mediates the relationship between perceived value and destination loyalty.

H7: Tourist satisfaction mediates the relationship between service quality and destination loyalty. 


\section{Research Methodology}

The target population in this study were international tourists who visited Malaysia for a holiday, business trip, conference, visiting friends or relatives for at least one day but less than one year (Mill and Morrison, 1985). This study was conducted from August 2014 to October 2014 using closed-ended structured questionnaire in order to collect all of the primary data (perceived value, service quality, tourist satisfaction and destination loyalty). Kuala Lumpur International airport (KLIA) was chosen as the location to conduct the pilot study and actual study because it is the major entrance and departure point of the international tourists who visit Malaysia. 900 questionnaires have been distributed to the tourists at the departure hall. However, only 694 questionnaires have been returned by the respondents resulting in a response rate of 77.1 percent. Since accurate data pertaining to the size of this population was not available, sampling frame was created based on the 694 questionnaires. This study has selected the respondents using simple random sampling method because it can reduce the potential of human bias in the selection of cases to be included in the sample (Sekaran and Bougie, 2016). Statistical Package for Social Science (SPSS) software was used to select the respondents by "Random Sample of Cases". In this case, 347 out of 694 respondents were selected as the sample size (50 percent from the returned questionnaire). However, after operating data-cleaning process through deleting the outliers, only 337 respondents were used to analyse the data which is still within the sample size required by Burn et al. (2017).

The questionnaire of perceived value was adapted from the work of Lee et al. (2007) using 10-point rating scale ranging from 1 "strongly disagree" to 10 "strongly agree". The questionnaire of service quality was adapted from the work of Moutinho et al. (2007) using an interval scale from 1 as "very poor" to 10 as "very good". The questionnaire of tourist satisfaction was adapted from the work of Kim, et al. (2013) using an interval scale from 1 "strongly disagree" to 10 "strongly agree". The questionnaire of destination loyalty was adapted from the work of Sun, et al. (2013) using interval scale from 1 "strongly disagrees" to 10 "strongly agree". All the items measuring each of the constructs use the interval from 1 to 10 rating scale to ensure the data are more independent and fulfil the requirement for parametric analysis (Zainudin, 2015).

The collected data utilised several statistical analyses using Statistical Package for Social Science program (SPSS version 22) and Analysis of Moment Structure (AMOS version 23). The analysis procedure in SPSS was utilized to run the Exploratory Factor Analysis (EFA) using pilot study data. The Confirmatory Factor Analysis (CFA) was performed to validate all latent constructs in the study namely perceived value, destination service quality, tourist satisfaction and destination loyalty for validity and reliability. Once validated, Structural Equation Modeling (SEM) was applied to test the inter-relationships among perceived value, destination service quality, tourist satisfaction and destination loyalty in the structural model

\section{Results}

\section{Respondents' Profile}

The findings revealed that, most of the tourists who visited Malaysia were from Northern Europe (United Kingdom, Sweden, Ireland and Norway) (41.7\%) and Oceania region (Australia and New Zealand (36.0\%). Majority of the tourists were female which were $56.8 \%$. Most of the tourists were single and married (78.3\%) and representing age group from 15 to 34 years old $(51.3 \%)$. Majority of the tourists $(57.7 \%)$ indicated that their visits to Malaysia were their first. 91.0 percent of the international tourist purposely visited Malaysia to spend 
their holidays. On average, most tourists (37.0\%) spend between 5-10 days in Malaysia. They knew Malaysia as a tourist destination from information on the internet $(53.8 \%)$ and the positive word-of-mouth disseminated by their friends or relatives who visited Malaysia (44.8\%). While in Malaysia, majority of the tourists (91.3\%) choose to stay at hotels.

\section{Measurement Model Testing}

EFA was performed on data collected in a pilot study data to identify items manifesting perceived value, service quality, tourist satisfaction and destination loyalty. In addition, EFA was carried out to identify underlying factors. The reliability of the instrument was accessed through Cronbach's Alpha. A value of Cronbach's Alpha more than or equal to 0.7 suggested that the instruments achieved the internal reliability. CFA was carried out to validate the measurement model of latent constructs. Measurement model illustrates the relationship between the measured items and their underlying latent construct (Zainudin, 2015) which was evaluated by the technique of confirmatory factor analysis. CFA was conducted prior to testing the SEM model in order to establish confidence in the measurement model specifying the posited relations of the observed variables to the underlying constructs (Lee, Yoon and Lee, 2007). The test was conducted because confirmatory measurement model should be evaluated and re-specified before measurement and structural equation models are examined simultaneously (Yoon and Uysal, 2005). Each latent construct in the model was analysed separately and the CFA procedures run simultaneously for all the latent constructs (full measurement model).

Figure 2 depicts the pool measurement model of perceived value, service quality, tourist satisfaction and destination loyalty. Item purification has been conducted and some items have been eliminated with factor loading below 0.5 . Table 1 presents the items that measured perceived value, service quality, tourist satisfaction and destination loyalty.

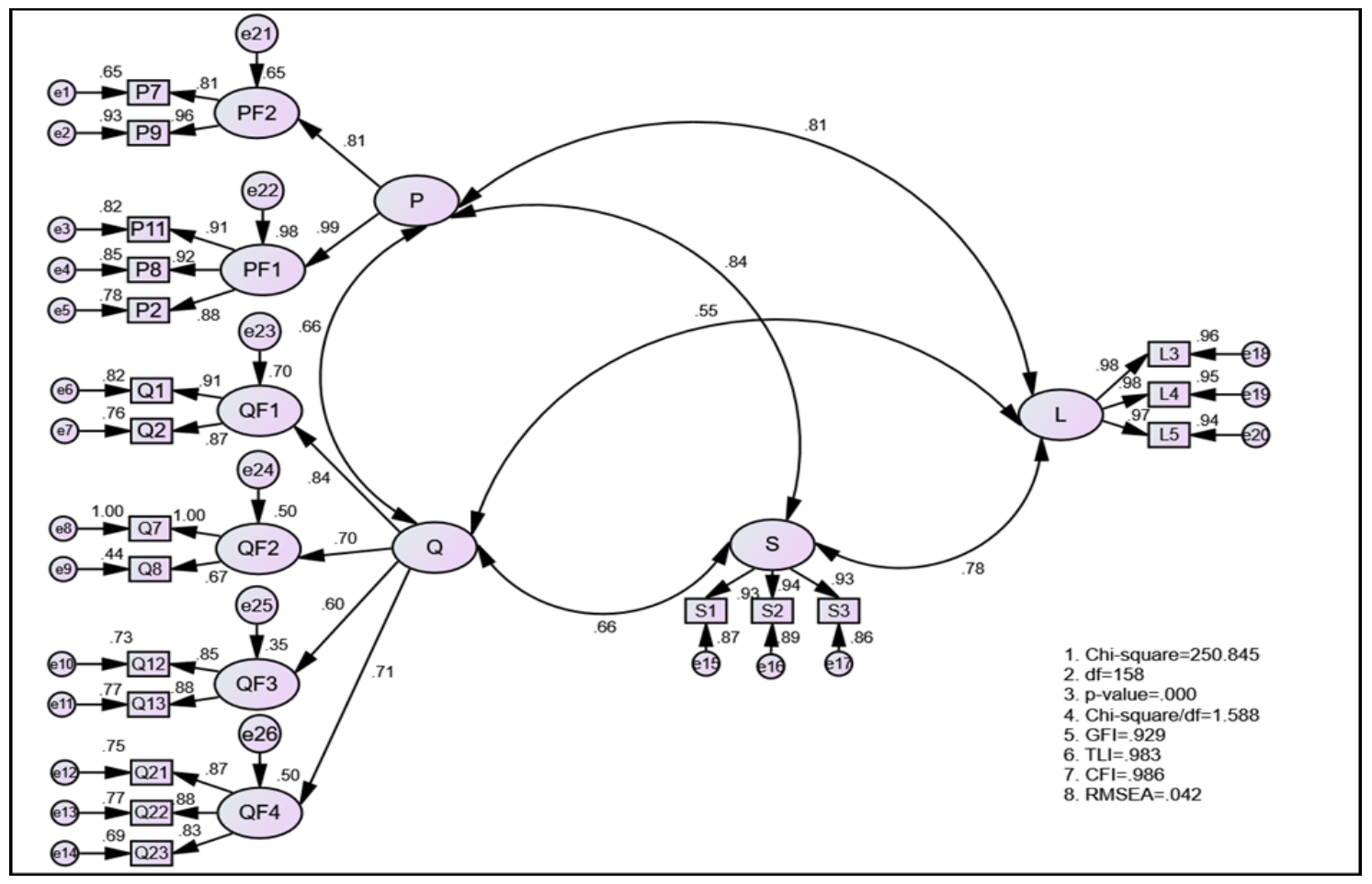

Figure 2: The Pooled Measurement Model of Perceived Value, Service Quality, Tourist Satisfaction and Destination Loyalty 


\section{Assessment of Normality, Reliability and Validity}

CFA has the capability to assess the unidimensionality, reliability and validity of the latent constructs prior to modelling the relationship into structural model (Zainudin, 2015). Table 1 illustrates the values of factor loading, CR and AVE of the constructs under study. The values of factor loadings, more than 0.6 , suggested that the constructs of perceived value, service quality, tourist satisfaction and destination loyalty achieved unidimensionality requirement. Reliability requirement was assessed using CR. The findings in Table 1 suggested that the reliability requirement is achieved where CR values of all constructs are more than 0.6. Validity of the measurement model was assessed using convergent validity measured by AVE and discriminant validity. The values of AVE (more than 0.5) suggested that the model achieved adequate convergent validity.

Table 1: The Validity and Reliability of the Measurement Model

\begin{tabular}{|c|c|c|c|c|}
\hline Construct & Item & Loading & $\begin{array}{c}\text { CR } \\
\text { (above } \\
\text { 0.6) }\end{array}$ & $\begin{array}{l}\text { AVE } \\
\text { (above } \\
\text { 0.6) }\end{array}$ \\
\hline \multirow[t]{2}{*}{ Perceived Value } & Overall Value (PF1) & 0.99 & 0.90 & 0.82 \\
\hline & Functional Value (FF2) & 0.81 & & \\
\hline \multirow[t]{3}{*}{$\begin{array}{l}\text { Overall Value } \\
\text { (PF1) }\end{array}$} & $\begin{array}{l}\text { I obtained good results from visiting } \\
\text { Malaysia (P2) }\end{array}$ & 0.88 & 0.93 & 0.82 \\
\hline & $\begin{array}{l}\text { Malaysia is a destination that I enjoy } \\
\text { (P8) }\end{array}$ & 0.92 & & \\
\hline & $\begin{array}{l}\text { Visiting Malaysia gave me pleasure } \\
\text { (P11) }\end{array}$ & 0.91 & & \\
\hline \multirow[t]{2}{*}{$\begin{array}{l}\text { Functional Value } \\
\text { (PF2) }\end{array}$} & $\begin{array}{l}\text { Compared to other tourism } \\
\text { destinations, visiting Malaysia is good } \\
\text { value for money (P7) }\end{array}$ & 0.81 & 0.88 & 0.79 \\
\hline & $\begin{array}{l}\text { Compared to travel expenses, I got } \\
\text { reasonable quality experience from } \\
\text { visiting Malaysia (P9) }\end{array}$ & 0.96 & & \\
\hline \multirow[t]{4}{*}{ Service Quality } & Shopping (QF1) & 0.84 & 0.81 & 0.52 \\
\hline & Health and Hygiene (QF2) & 0.70 & & \\
\hline & Information and Facilities (QF3) & 0.60 & & \\
\hline & Accommodation (QF4) & 0.71 & & \\
\hline \multirow[t]{2}{*}{ Shopping (QF1) } & $\begin{array}{l}\text { Attitudes of the shopkeepers towards } \\
\text { tourists (Q1) }\end{array}$ & 0.91 & 0.88 & 0.79 \\
\hline & Honesty of the shopkeepers (Q2) & 0.87 & & \\
\hline \multirow[t]{2}{*}{$\begin{array}{l}\text { Health and } \\
\text { Hygiene (QF2) }\end{array}$} & $\begin{array}{l}\text { Cleanliness of the food and beverage } \\
\text { facilities (Q7) }\end{array}$ & 1.00 & 0.83 & 0.72 \\
\hline & Cleanliness of the public toilets (Q8) & 0.67 & & \\
\hline \multirow[t]{2}{*}{$\begin{array}{l}\text { Information and } \\
\text { Facilities (QF3) }\end{array}$} & $\begin{array}{l}\text { Opportunities to obtain maps, } \\
\text { brochures, etc. about the region }(\mathrm{Q} 12)\end{array}$ & 0.85 & 0.86 & 0.75 \\
\hline & Informative signs and symbols (Q13) & 0.88 & & \\
\hline \multirow{3}{*}{$\begin{array}{l}\text { Accommodation } \\
\text { (QF4) }\end{array}$} & General cleanliness of the hotel (Q21) & 0.87 & 0.89 & 0.74 \\
\hline & $\begin{array}{l}\text { Food and beverage quality at the hotel } \\
\text { (Q22) }\end{array}$ & 0.88 & & \\
\hline & Attitudes of the hotel staff (Q23) & 0.83 & & \\
\hline Tourist & Overall, I am satisfied with Malaysia & 0.93 & 0.95 & 0.87 \\
\hline
\end{tabular}




\begin{tabular}{lllll}
\hline Satisfaction & (S1) & & & \\
\cline { 2 - 5 } & $\begin{array}{l}\text { I am satisfied with Malaysia compared } \\
\text { with my expectation (S2) }\end{array}$ & 0.94 & & \\
& $\begin{array}{l}\text { Satisfied with Malaysia when } \\
\text { considering time and effort I invested } \\
\text { (S3) }\end{array}$ & 0.93 & & \\
& $\begin{array}{l}\text { I will recommend Malaysia to friends } \\
\text { (L3) }\end{array}$ & 0.98 & 0.98 & 0.95 \\
\hline $\begin{array}{l}\text { Destination } \\
\text { Loyalty }\end{array}$ & $\begin{array}{l}\text { I wembers (L4) } \\
\text { I will encourage other people to visit } \\
\text { Malaysia (L5) }\end{array}$ & 0.97 & \\
\hline
\end{tabular}

Discriminant validity was used to measure the extent to which a construct is really different from other constructs (Hair et al., 2010). The findings in Table 2 suggested that all constructs in the study achieved discriminant validity requirement. The values of square root of the average variance extracted of each construct (diagonal values in bold) are higher than the values of the correlations between each construct.

Table 2: The Discriminant Validity Index Summary

\begin{tabular}{lllll}
\hline \multicolumn{1}{c}{ Construct } & Perceived Value & $\begin{array}{l}\text { Service } \\
\text { Quality }\end{array}$ & Satisfaction & Loyalty \\
\hline Perceived Value & $\mathbf{0 . 9 1}$ & & & \\
\hline Service Quality & 0.66 & $\mathbf{0 . 7 2}$ & & \\
\hline Satisfaction & 0.84 & 0.66 & $\mathbf{0 . 9 3}$ & $\mathbf{0 . 9 7}$ \\
\hline Loyalty & 0.81 & 0.55 & 0.78 & \\
\hline
\end{tabular}

\section{Structural Model}

The structural equation modelling (SEM) analysis was conducted using the maximum likelihood (ML) estimation method to examine the relationships between each pair of constructs (perceived value, service quality, tourist satisfaction and destination loyalty). Before proceeding to the path analysis, it is important to check for the model fit. The fit indices of the structural model indicated that the model achieved adequate level of goodnessof-fit with NCI $(\chi 2 / \mathrm{df})=1.588$, GFI $=0.929$, TLI $=0.983, \mathrm{CFI}=0.986$, and RMSEA $=$ 0.042 , suggesting that the study fits the sample data adequately well (see Table 3 ). 


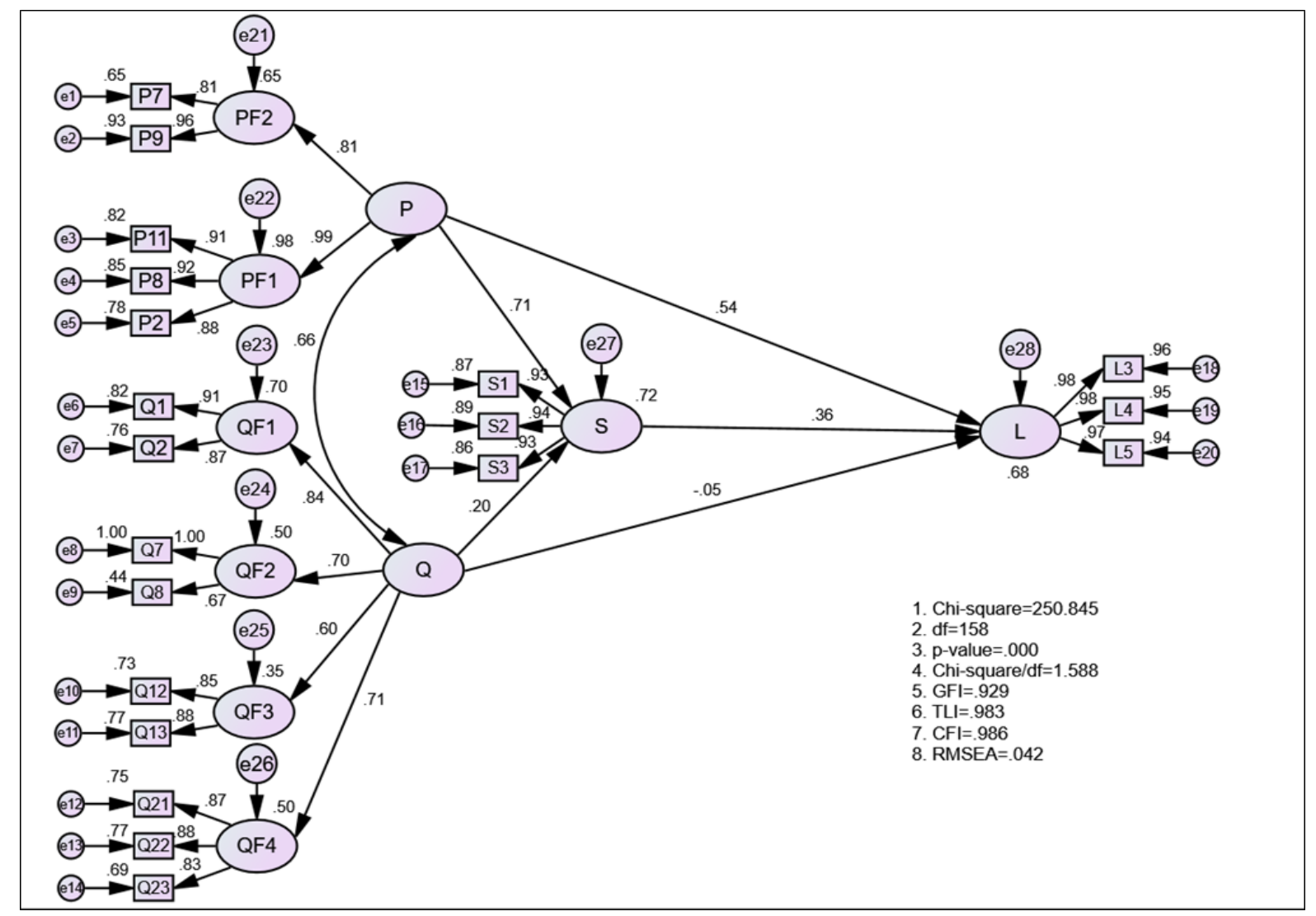

Figure 3: Structural Model of Perceived Value, Service Quality, Tourist Satisfaction and Destination Loyalty

Table 3: Goodness-of-fit Indices for The Measurement and Structural Model

\begin{tabular}{llrl}
\hline Index & $\begin{array}{l}\text { Level } \\
\text { acceptance }\end{array}$ & $\begin{array}{l}\text { of } \\
\text { Measurement } \\
\text { Model }\end{array}$ & $\begin{array}{l}\text { Structural } \\
\text { Model }\end{array}$ \\
\hline Absolute fit: & $>0.90$ & 0.929 & 0.929 \\
\hline GFI & $<0.08$ & 0.042 & 0.042 \\
\hline RMSEA & & & \\
\hline Incremental fit: & $>0.90$ & 0.986 & 0.986 \\
\hline CFI & $>0.90$ & 0.983 & 0.983 \\
\hline TLI & & & \\
\hline Parsimonious fit: & $<2.00$ & 1.588 & 1.588 \\
\hline NCI $\left(\chi^{2} / \mathrm{df}\right)$ & & & \\
\hline
\end{tabular}

The study proposed several hypotheses to be tested using Structural Equation Modelling (SEM). There were five direct hypotheses (Path Analysis). Table 4 indicated that four out of the five proposed hypotheses were supported. The finding of the study did not support Hypothesis 4. The first hypothesis (H1) revealed that there was a positive relationship between perceived value and tourist satisfaction. This finding has been supported by Gallarza and Saura (2006), Lee et al. (2007), Chen and Chen (2010) and Milfelner et al. (2011). The second hypothesis (H2) proposed that perceived value has direct effect on destination loyalty. This result paralleled with the previous study conducted by Mechinda et al. (2010), Meng et al. (2011) and Moutinho et al. (2012) which have shown significant positive relationship between perceived value and destination loyalty. Hypothesis three $(\mathrm{H} 3)$ proposed that service 
quality has direct effect on tourist satisfaction. According to Leong et al. (2015), the relationship between service quality and customer satisfaction has been broadly debated where some researchers stated that service quality can produce customer satisfaction while others are not agreeing or argued that there is no relationship between these two constructs. In this study, the finding corresponded with what has been proposed by Lee et al. (2011), Kim et al. (2013) and Rajaratnam et al. (2014) where service quality has a significant positive influence on tourist satisfaction. Hypothesis four $(\mathrm{H} 4)$ proposed that service quality has direct effect on destination loyalty. However, in this study, the result of the Hypothesis 4 revealed that service quality has no significant direct effect on destination loyalty. A study from Chen and Chen (2010) supported this finding where service quality has no significant effect on destination loyalty. Hypothesis five (H5) proposed that tourist satisfaction has direct effect on destination loyalty. This result paralleled with previous study conducted by Chi and Qu (2008), Tsung (2009), Ling et al. (2010), Ahmad Puad Mat Som et al. (2011) and Mahadzirah et al. (2014), which have shown significant positive relationship between tourist satisfaction and destination loyalty.

Table 4: Regression Weights

\begin{tabular}{|c|c|c|c|c|c|c|c|c|}
\hline Construct & Path & Construct & Estimate & S.E. & C.R. & $\begin{array}{c}\text { P- } \\
\text { value }\end{array}$ & Hypothesis & Result \\
\hline $\begin{array}{l}\text { Tourist } \\
\text { Satisfaction } \\
\text { (S) }\end{array}$ & $<---$ & $\begin{array}{l}\text { Perceived } \\
\text { Value }(\mathrm{P})\end{array}$ & 0.826 & 0.076 & 10.921 & $* * *$ & $\begin{array}{l}\text { Hypothesis } \\
1\end{array}$ & Significant \\
\hline $\begin{array}{l}\text { Destination } \\
\text { Loyalty (L) }\end{array}$ & $<---$ & $\begin{array}{l}\text { Perceive } \\
\text { Value }(\mathrm{P})\end{array}$ & 0.715 & 0.119 & 6.016 & $* * *$ & $\begin{array}{l}\text { Hypothesis } \\
2\end{array}$ & Significant \\
\hline $\begin{array}{l}\text { Tourist } \\
\text { Satisfaction } \\
\text { (S) }\end{array}$ & $<---$ & $\begin{array}{l}\text { Service } \\
\text { Quality (Q) }\end{array}$ & 0.205 & 0.063 & 3.279 & 0.001 & $\begin{array}{l}\text { Hypothesis } \\
3\end{array}$ & Significant \\
\hline $\begin{array}{l}\text { Destination } \\
\text { Loyalty (L) }\end{array}$ & $<---$ & $\begin{array}{l}\text { Service } \\
\text { Quality (Q) }\end{array}$ & -0.056 & 0.068 & -0.816 & 0.414 & $\begin{array}{l}\text { Hypothesis } \\
4\end{array}$ & $\begin{array}{l}\text { Not } \\
\text { Significant }\end{array}$ \\
\hline $\begin{array}{l}\text { Destination } \\
\text { Loyalty (L) }\end{array}$ & $<---$ & $\begin{array}{l}\text { Tourist } \\
\text { Satisfaction } \\
\text { (S) }\end{array}$ & 0.405 & 0.091 & 4.427 & $* * *$ & $\begin{array}{l}\text { Hypothesis } \\
5\end{array}$ & Significant \\
\hline
\end{tabular}

\section{The Mediation Analysis}

Mediation analysis was conducted to identify the type of mediation existing in the model (Aimran et al., 2016). There were two hypotheses focusing on testing the mediating effect of tourist satisfaction between perceived value and destination loyalty and service quality and destination loyalty. Bootstrap approach has been used to confirm the type of mediation existing in the model (Aimran et al., 2016). H6 proposed that tourist satisfaction mediates the relationship between perceived value and destination loyalty. The finding in this study found that no mediation occurred since the direct effect is higher than the indirect effect based on the bootstrapping results $(\beta)$ as depicted in Table 5. Thus, it did not support the H6 of the study. $\mathrm{H} 7$ proposed that tourist satisfaction mediates the relationship between service quality and destination loyalty. However, $\mathrm{H} 7$ of this study revealed a full mediation occurred since the relationship between service quality and destination loyalty was not significant as illustrated in Table 5. 
Table 5: The Results of Bootstrapping Procedure in testing the mediating effects of Perceived Value, Service Quality and Destination Loyalty

\begin{tabular}{|c|c|c|c|c|}
\hline & \multicolumn{2}{|c|}{ Hypothesis 6} & \multicolumn{2}{|c|}{ Hypothesis 7} \\
\hline & $\begin{array}{l}\text { Indirect Effect } \\
P \rightarrow L\end{array}$ & $\begin{array}{l}\text { Direct Effect } \\
P \rightarrow L\end{array}$ & $\begin{array}{l}\text { Indirect Effect } \\
\mathbf{Q} \rightarrow \mathbf{L}\end{array}$ & $\begin{array}{l}\text { Direct Effect } \\
\mathbf{Q} \rightarrow \mathbf{L}\end{array}$ \\
\hline $\begin{array}{l}\text { Bootstrapping } \\
\text { Results }\end{array}$ & 0.25 & 0.54 & 0.70 & -0.05 \\
\hline $\begin{array}{l}\text { Bootstrapping } \\
\text { P-value }\end{array}$ & 0.002 & 0.002 & 0.007 & 0.45 \\
\hline Result & Significant & Significant & Significant & Not Significant \\
\hline $\begin{array}{l}\text { Type of } \\
\text { Mediation }\end{array}$ & \multicolumn{2}{|c|}{$\begin{array}{l}\text { The mediation does not exist since } \\
\text { the direct effect is higher than the } \\
\text { indirect effect based on the } \\
\text { bootstrapping results }(\beta)\end{array}$} & \multicolumn{2}{|c|}{$\begin{array}{l}\text { Full Mediation since direct } \\
\text { relationship is not significant }\end{array}$} \\
\hline
\end{tabular}

\section{Conclusions}

In the Tenth Malaysia Plan, Malaysia had targeted itself to be in the top ten as regards tourist receipts in the world during 2015. However, Malaysia failed to position itself in the world ranking as intended. In the stiff competition among the destinations in the world for the potential tourists to travel to Malaysia, the study on destination loyalty is extremely vital. Thus, acquiring tourist' loyalty toward destination (Malaysia) is the focal point in this study as it may result in remarkable benefits to the nation in the future. The primary objectives of this study were to investigate and develop a theoretical relationship among perceived value and service quality and to empirically test the constructs that are likely to affect tourist satisfaction, which in turn influence destination loyalty.

The results of empirical study indicated that perceived value influenced tourist satisfaction and destination loyalty. In addition, the findings revealed that service quality had a significant effect on satisfaction. However, service quality had no significant effect on destination loyalty. Moreover, the findings indicated that tourist satisfaction had a full mediating effect on the relationship between service quality and destination loyalty. The study contributed to a better understanding of behavioural factors that would represent a sustainable source for increasing customer retention at the level of individual providers as well as a destination as a whole. Individual providers should focus on delivering quality services related to accommodation, information and facilities, health and hygiene, and shopping that were associated to a visitor's travel experience. Aspects of perceived value identified in the study could be used as a strategic tool in managing tourism offerings which could enhance the destination's competitive edge.

\section{Limitation and Recommendation}

This study was conducted not without limitations. Firstly, the study was a snapshot study conducted during the months of August 2014 to October 2014. The findings of this study were limited only to international tourists who travelled during this period of time. Tourists who travel in different seasons could have different views of Malaysia as a tourism destination. Future researchers may conduct similar surveys in different seasons to overcome this limitation. Secondly, the collection of the data was conducted at Kuala Lumpur International Airport (KLIA). Therefore, this study excluded tourists who did not depart from these airports. Therefore, the findings of this study may not be generalized beyond this population. Replicating similar studies in other tourist destinations would be imperative for 
increasing the generalizability of these findings. Finally, the data collected from this study were cross sectional and could not be used to analyse behaviour over a period of time. Future researchers would benefit from the collection of longitudinal data to precisely measure change over a period of time and the direction of causality among relationships.

\section{Acknowledgement}

This study was funded by the Fundamental Research Grant Scheme, Universiti Sultan Zainal Abidin, Malaysia.

\section{References}

Ahmad Puad Mat Som \& Badarneh, M. B. (2011). Tourist satisfaction and repeat visitation: toward a new comprehensive model. International Journal of Human and Social Sciences, 6(1), 38-45.

Aimran, A. N., Ahmad, S., \& Afthanorhan, A. (2016). Confirming the Mediation Effect of A Structural Model By Using Bootstrap Approach: A Case Study of Malaysian 8th Grade Students' Mathematics Achievement. International Journal of Business, Economics and Management, 3(4), 44-51.

Akroush, M. N., Jraisat, L. E., Kurdieh, D. J., AL-Faouri, R. N., \& Qatu, L. T. (2016). Tourism service quality and destination loyalty-the mediating role of destination image from international tourists' perspectives. Tourism Review, 71(1), 18 - 44.

Alizadeh, A., \& Saghafi, G. (2014). An Examination of Antecedents of Loyalty Intention to Travel: The Case of Malaysia. Proceedings of the First Middle East Conference on Global Business, Economics, Finance and Banking Dubai, 10-12 October 2014.

Bajs, I. P. (2015). tourist perceived value, relationship to satisfaction, and behavioral intentions: the example of the Croatian tourist destination Dubrovnik. Journal of Travel Research, 54(1), 122-134.

Bhuiyan, A. H., Siwar, C., \& Ismail, S. M. (2013). Tourism Development in Malaysia from the Perspective of Development Plans. Asian Social Science, 9(9), 11-18. http://doi.org/10.5539/ass.v9n9p11.

Burn, A. C. \& Bush, R. F. (2010). Marketing Research (6th ed.). New Jersey: Upper Saddle River.

Burn, A. C. Veeck, A. \& Bush, R. F. (2017). Marketing Research (8th ed.). Malaysia: Pearson Education Limited.

Campón, A. M., Alves, H., \& Hernández, J. M. (2013). Loyalty measurement in tourism: A theoretical reflection. In quantitative methods in tourism economics (pp. 13-40). Physica-Verlag HD.

Chen, C. F., \& Chen, F. S. (2010). Experience quality, perceived value, satisfaction and behavioral intentions for heritage tourists. Tourism Management, 31(1), 29-35.

Chen, C. F., \& Tsai, D. (2007). How destination image and evaluative factors affect behavioral intentions? Tourism Management, 28(4), 1115-1122.

Chi, C. G. \& Qu, H. (2008). Examining the structural relationships of destination image, tourist satisfaction and destination loyalty: An integrated approach, Tourism Management, 29, 624-636.

Deng, J., \& Pierskalla, C. (2011). Impact of past experience on perceived value, overall satisfaction, and destination loyalty: A comparison between visitor and resident attendees of a festival. Event Management, 15(2), 163-177.

Eid, R., \& El-Gohary, H. (2014). Muslim tourist perceived value in the hospitality and tourism industry. Journal of Travel Research, 1-14. 
Gallarza, M. G., \& Saura, I. G. (2006). Value dimensions, perceived value, satisfaction and loyalty: an investigation of university students' travel behaviour. Tourism Management, 27(3), 437-452.

Hair, J. F., Black, W. C., Babin, B. J., Anderson, R. E. \& Tatham, R. L. (2010). Multivariate Data Analysis (7th ed.). New Jersey: Pearson Prentice Hall.

Hallak, R., Assaker, G., \& El-Haddad, R. (2018). Re-examining the relationships among perceived quality, value, satisfaction, and destination loyalty: A higher-order structural model. Journal of Vacation Marketing, 24(2), 118-135.

Hallem, Y., \& Barth, I. (2011). Customer-perceived value of medical tourism: An exploratory study - the case of cosmetic surgery in Tunisia. Journal of Hospitality and Tourism Management, 18(1), 121-129.

Hallmann, K., Zehrer, A., \& Müller, S. (2015). Perceived destination image: an image model for a winter sports destination and its effect on intention to revisit. Journal of Travel Research, 54(1), 94-106.

Kaur, H., \& Soch, H. (2012). Validating antecedents of customer loyalty for Indian cell phone users. Vikalpa, 37(4), 47-61.

Khan, A.H., Haque, A.K.M. \& Rahman, S. (2013). What makes tourists satisfied? An empirical study on Malaysian Islamic tourist destination. Middle East Journal of Scientific Research, Vol. 14, No. 12, pp. 1631-1637.

Khuong, M.N. \& Ha, H.T.T. (2014). The influences of push and pull factors on the international leisure tourists' return intention to Ho Chi Minh City, Vietnam: a mediation analysis of destination satisfaction. International Journal of Trade, Economics and Finance, 5, 490-496.

Kim, S. H., Holland, S. \& Han, H. S. (2013). A structural model for examining how destination image, perceived value and service quality affect destination loyalty: A case study of Orlando. International Journal of Tourism Research, 15, 313-328.

Lee, C. K., Yoon, Y.S. \& Lee, S. K. (2007). Investigating the relationships among perceived value, satisfaction and recommendations: The case of the Korean DMZ. Tourism Management, 28, 204-214.

Lee, S., Jeon, S. \& Kim, D. (2011). The impact of tour quality and tourist satisfaction on tourist loyalty: The case of Chinese tourists to Korea. Tourism Management, 32, 11151124.

Leong, L. Y., Hew, T. S., Lee, V. H., \& Ooi, K. B. (2015). An SEM-artificial-neural-network analysis of the relationships between SERVPERF, customer satisfaction and loyalty among low-cost and full-service airline. Expert Systems with Applications, 42(19), 6620-6634.

Ling, L. Q., Muhd Shahrim Ab Karim, Mohhidin Othman, Noranizan Mohd Adzahan and Sridar Ramachandran (2010). Relationship between Malaysia food image, tourist satisfaction and behavioral intention. World Applied Sciences Journal 10 (Special Issues of Tourism \& Hospitality), 164-171.

Mahadzirah Mohamad, Nur Izzati Ab Ghani, Mustafa Mamat \& Ibrahim Mamat (2014). Satisfaction as a Mediator to the Relationships between Destination Image and Loyalty. World Applied Sciences Journal, 30(9), 1113-1123.

Malaysia Airports Holdings Berhad (2013). Malaysia Airports 2013 Annual Report. Retrieved from http://ir.chartnexus.com/malaysiaairports/doc/ar/ar2013.pdf

Malhotra, N. K. (2007). Marketing research: An applied orientation (5th Ed.). New Delhi: Prentice-Hall. 
Mao, I. Y. \& Zhang, H. Q. (2014). Structural relationships among destination preference, satisfaction and loyalty in Chinese tourists to Australia. International Journal of Tourism Research, 16(2), 201-208.

Matsuoka, K., Hallak, R., Murayama, T., \& Akiike, A. (2017). Examining the effects of perceived quality, value, satisfaction, and destination loyalty in Shiogama, Japan. Tourism Review International, 21(1), 3-16.

Mazlina Jamaludin, Shazali Johari, Azlizam Aziz, Kalsom Kayat \& Abdul Raheem Mohamad Yusof (2012). Examining structural relationship between destination image, tourist satisfaction and destination loyalty. International Journal of Independent Research and Studies, 1(3), 89-96.

Mechinda, P., Serirat, S., Anuwichanont, J., \& Gulid, N. (2010). An examination of tourists' loyalty towards medical tourism in Pattaya, Thailand. International Business \& Economics Research Journal (IBER), 9(1), 55-70.

Mechinda, P., Serirat, S., Anuwichanont, J., \& Gulid, N. (2010). An examination of tourists' loyalty towards medical tourism in Pattaya, Thailand. International Business \& Economics Research Journal (IBER), 9(1), 55-70.

Meleddu, M., Paci, R., \& Pulina, M. (2015). Repeated behaviour and destination loyalty. Tourism Management, 50, 159-171.

Meng, S. M., Liang, G. S., \& Yang, S. H. (2011). The relationships of cruise image, perceived value, satisfaction, and post-purchase behavioral intention on Taiwanese tourists. African Journal of Business Management, 5(1), 19-29.

Menteri, Jabatan Perdana. (2010). Economic Transformation Programme: A Roadmap for Malaysia (1 Malaysia). Kuala Lumpur, Performance Management and Delivery Unit (PEMANDU).

Milfelner, B., Snoj, B., \& Pisnik Korda, A. (2011). Measurement of Perceived Quality, Perceived Value, Image, and Satisfaction Interrelations of Hotel Services: Comparison of Tourists from Slovenia and Italy. Social Issues-Journal for General Social Issues, 3 (113), 605-624.

Mill, R. C. \& Morisson, A., (1985). The Tourism System. Hempstead: Prentice Hall.

Mohamad, M., Ali, A. M., Ab Ghani, N. I., Abdullah, A. R., \& Mokhlis, S. (2012). Positioning Malaysia as a tourist destination based on destination loyalty. Asian Social Science, 9(1), 286.

Moon, K. S., Ko, Y. J., Connaughton, D. P., \& Lee, J. H. (2013). A mediating role of destination image in the relationship between event quality, perceived value, and behavioral intention. Journal of Sport \& Tourism, 18(1), 49-66.

Mosbah, A., Saleh, M., \& Al, A. (2014). A Review of Tourism Development in Malaysia. European Journal of Business and Management, 6(5), 1-9.

Moutinho, L., Albayrak, T. \& Caber, M. (2012). How far does overall service quality of a destination affect customers' post-purchase behaviours? International Journal of Tourism Research, 14, 307-322.

Moutinho, L., Albayrak, T. \& Caber, M. (2012). How far does overall service quality of a destination affect customers' post-purchase behaviours? International Journal of Tourism Research, 14, 307-322.

Oppermann, M. (2000). Tourism destination loyalty. Journal of Travel Research, 39, 78-84.

Othman, R., Salleh, N. H. M. \& Sarmidi, T. (2012). Analysis of causal relationship between tourism development, economic growth and foreign direct investment: An ARDL Approach. Journal of Applied Sciences, 12(12), 1245-1254. 
Paramati, S. R., Alam, M. S., \& Chen, C. F. (2017). The effects of tourism on economic growth and $\mathrm{CO} 2$ emissions: a comparison between developed and developing economies. Journal of Travel Research, 56(6), 712-724.

Phillips, W. J., Wolfe, K., Hodur, N., \& Leistritz, F. L. (2013). Tourist word of mouth and revisit intentions to rural tourism destinations: A case of North Dakota, USA. International Journal of Tourism Research, 15(1), 93-104.

Priporas, C. V., Stylos, N., Vedanthachari, L. N., \& Santiwatana, P. (2017). Service quality, satisfaction, and customer loyalty in Airbnb accommodation in Thailand. International Journal of Tourism Research, 19(6), 693-704.

Rajaratnam, S. D., Munikrishnan, U. T., Sharif, S. P., \& Nair, V. (2014). Service quality and previous experience as a moderator in determining tourists' satisfaction with rural tourism destinations in Malaysia: A partial least squares approach. Procedia-Social and Behavioural Sciences, 144, 203-211.

Rajaratnam, S. D., Nair, V., Pahlevan Sharif, S., \& Munikrishnan, U. T. (2015). Destination quality and tourists' behavioral intentions: rural tourist destinations in Malaysia. Worldwide Hospitality and Tourism Themes, 7(5), 463-472.

Sato, S., Gipson, C., Todd, S., \& Harada, M. (2018). The relationship between sport tourists' perceived value and destination loyalty: an experience-use history segmentation approach. Journal of Sport \& Tourism, 22(2), 173-186.

Schiffman, L. G. \& Kanuk, L. L. (2007). Consumer behavior (9th ed.). New Jersey: Pearson Prentice Hall.

Sekaran, U., \& Bougie, R. (2016). Research methods for business: A skill building approach (6th ed.). United Kingdom: John Wiley and Sons Ltd.

Silvestri, C., Aquilani, B., \& Ruggieri, A. (2017). Service quality and customer satisfaction in thermal tourism. The TQM Journal, 29(1), 55-81.

Sun, X., Chi, C. G. Q. \& Xu, H. (2013). Developing destination loyalty: The case of Hainan Island. Annals of Tourism Research, 43, 547-577.

Tiru, M., Kuusik, A., Lamp, M. L., \& Ahas, R. (2010). LBS in marketing and tourism management: measuring destination loyalty with mobile positioning data. Journal of Location Based Services, 4(2), 120-140.

Tosun, C., Dedeoğlu, B. B., \& Fyall, A. (2015). Destination service quality, affective image and revisit intention: The moderating role of past experience. Journal of Destination Marketing \& Management, 4(4), 222-234.

Travel and Tourism Competitiveness Report (2017). Retrieved on 4 February 2018 from http://www3.weforum.org/docs/WEF_TTCR_2017_web_0401.pdf

Tsung, H. L. (2009). A structural model to examine how destination image, attitude and motivation affect the future behavior of tourists. Leisure Sciences, 31, 215-236.

Vassiliadis, C., Bista, R., \& Fotiadis, A. (2008). Basic service quality dimensions in tourist destination planning. Journal of Tourism Challenges and Trends, 1(2), 33-44.

Wang, B., Yang, Z., Han, F., \& Shi, H. (2016). Car tourism in Xinjiang: The mediation effect of perceived value and tourist satisfaction on the relationship between destination image and loyalty. Sustainability, 9(1), 22.

Wang, X., Zhang, J., Gu, C. \& Zhen, F. (2009). Examining antecedents and consequences of tourist satisfaction: A structural modeling approach. Tsinghua Science and Technology, 14(3), 397-406.

Wen, C. H. (2011). A study of tourists on attraction, service quality, perceived value and behavioural intention in the Penghu Ocean Firework festival. The Journal of International Management Studies, 7(2), 79-92. 
World Travel and Tourism Council (2012), Travel and Tourism Economic Impact 2011 Malaysia. Retrieved on 25th December 2016, from http://www.wttc.org//media/files/reports/economic\%20impact\%20research/regions\%202016/world2016.pd $\mathrm{f}$

World Travel and Tourism Council (2013), Travel and Tourism Economic Impact 2012 Malaysia. Retrieved on 25th December 2016, from http://www.wttc.org//media/files/reports/economic\%20impact\%20research/regions\%202012/world2012.pd $\mathrm{fWu}, \mathrm{C}$. W. (2015). Destination loyalty modeling of the global tourism. Journal of Business Research.

World Travel and Tourism Council (2018), Travel and Tourism Economic Impact 2017 Malaysia. Retrieved on 8th April 2018, from https://www.wttc.org//media/files/reports/economic-impact-research/countries2018/malaysia2018.pdf.

$\mathrm{Wu}, \mathrm{C}$. W. (2016). Destination loyalty modeling of the global tourism. Journal of Business Research, 69(6), 2213-2219.

Yoon, Y., \& Uysal, M. (2005). An examination of the effects of motivation and satisfaction on destination loyalty: a structural model. Tourism Management, 26(1), 45-56.

Žabkar, V., Brenčič, M. M., \& Dmitrović, T. (2010). Modelling perceived quality, visitor satisfaction and behavioural intentions at the destination level. Tourism management, 31(4), 537-546.

Zainudin, A. (2014). A handbook on SEM: for academics and practitioners. MPWS Rich Resources, Selangor.

Zainudin, A. (2015). SEM made simple: A gentle approach to learning structural equation modeling. MPWS Rich Publication, Bandar Baru Bangi.

Zikmund, W. G. \& Babib, B. J. (2010). Essentials of Marketing Research (4th ed.). USA: South-Western Cengage Learning. 